\title{
Toxicity and motor changes in Africanized honey bees (Apis mellifera L.) exposed to fipronil and imidacloprid
}

\author{
THAÍS S. BOVI ${ }^{1}$, RODRIGO ZALUSKI ${ }^{1}$ and RICARDO O. ORSI ${ }^{1,2}$

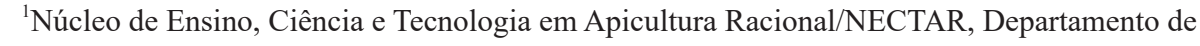 \\ Produção Animal, Faculdade de Medicina Veterinária e Zootecnia, Universidade Estadual Paulista/ \\ UNESP, Distrito de Rubião Junior, s/n, Caixa Postal 560, 18618-970 Botucatu, SP, Brazil \\ ${ }^{2}$ Universidade Estadual Paulista/UNESP, Centro de Estudos de Venenos e Animais Peçonhentos, Rua \\ José Barbosa de Barros, 1780, Fazenda Experimental Lageado, 18610-307 Botucatu, SP, Brazil
}

Manuscript received on March 16, 2015; accepted for publication on November 27, 2015

\begin{abstract}
This study evaluated the in vitro toxicity and motor activity changes in African-derived adult honey bees (Apis mellifera L.) exposed to lethal or sublethal doses of the insecticides fipronil and imidacloprid. Mortality of bees was assessed to determine the ingestion and contact lethal dose for $24 \mathrm{~h}$ using probit analysis. Motor activities in bees exposed to lethal $\left(\mathrm{LD}_{50}\right)$ and sublethal doses $\left(1 / 500^{\text {th }}\right.$ of the lethal dose $)$ of both insecticides were evaluated in a behavioral observation box at 1 and $4 \mathrm{~h}$. Ingestion and contact lethal doses of fipronil were $0.2316 \pm 0.0626$ and $0.0080 \pm 0.0021 \mu \mathrm{g} / \mathrm{bee}$, respectively. Ingestion and contact lethal doses of imidacloprid were $0.1079 \pm 0.0375$ and $0.0308 \pm 0.0218 \mu \mathrm{g} / \mathrm{bee}$, respectively. Motor function of bees exposed to lethal doses of fipronil and imidacloprid was impaired; exposure to sublethal doses of fipronil but not imidacloprid impaired motor function. The insecticides evaluated in this study were highly toxic to African-derived A. mellifera and caused impaired motor function in these pollinators.
\end{abstract}

Key words: environment, pesticides, pollinators, contamination, phenylpyrazoles, neonicotinoids.

\section{INTRODUCTION}

Honey bees are very important pollinators of crops and native vegetation, as well as producers of honey and other goods. Bees promote the crosspollination of vegetables, increasing genetic diversity in species and improving the production of fruit and seeds (Klein et al. 2007). The value of pollination to agriculture, provided primarily by bees, is $>\$ 200$ billion per annum worldwide, and in natural ecosystems it is thought to be even greater (Lebuhn et al. 2013).

Correspondence to: Ricardo de Oliveira Orsi

E-mail: orsi@fmvz.unesp.br
Managed bee colonies have suffered considerable losses in recent years, and reduced diversity of native bees has been observed worldwide (Oldroyd 2007, Stokstad 2007, Van Engelsdorp and Meixner 2010). A number of potential causes of reduced bee populations globally have been investigated, including habitat destruction and the scarcity of floral sources, the presence of pathogens and parasites (Oldroyd 2007, Williams et al. 2010), climate changes (Van Engelsdorp and Meixner 2010), improper management, queen-related issues (Williams et al. 2010), and high use of pesticides and adjuvants (Van Engelsdorp et al. 2009, Ciarlo 
et al. 2012). An additional cause of bee colony loss is the syndrome Colony Collapse Disorder (CCD). Colony Collapse Disorder is associated with multiple factors and characterized by rapid losses of worker bees, with few or no dead bees in or near the hives, abandoned brood and stored food, and delayed invasion of hive pests, has caused high colony losses (Oldroyd 2007, Van Engelsdorp et al. 2009).

Some colony losses are normal in beekeeping; however, it is clear that about once per decade, apiarists suffer unusually heavy colony losses, and there is a lack of understanding of the factors contributing to these declines (Oldroyd 2007). A recent major shift in agriculture has been the development and extensive deployment of phenylpyrazole and neonicotinoid pesticides that replace many of the older pesticides. These recently developed pesticides are used extensively on field, vegetable, turf, and ornamental crops, some of which are pollinated by bees (Ellis 2010). Due the high toxicity of these insecticides, some countries have banned the use of phenylpyrazoles (Ghisi et al. 2011), and the European Union restricts the use of three neonicotinoids (clothianidin, imidacloprid, and thiametoxam) for a period of two years, to review the risk of these pesticides to bees (Environmental Protection Agency 2015).

Other groups have demonstrated pesticide toxicity in A. mellifera and have implicated the role of pesticides in the decline of bee populations. The exposure of bees to pesticides has been associated with changes in behavior (Schneider et al. 2012, Henry et al. 2012, Zaluski et al. 2015), reductions in colony queen production (Whitehorn et al. 2012), morphologic alterations (Silva Cruz et al. 2010), foraging and survival reduction (Henry et al. 2012), damage to mitochondrial bioenergetics (Nicodemo et al. 2014), and negative impacts on honey bee health (Boncristiani et al. 2012).

Determining the toxicity of systemic pesticides such as phenylpyrazoles and neonicotinoids on honey bees is essential to establishing guidelines for controlled use in crops pollinated by bees. Our study was designed to establish the contact and ingestion lethal doses $\left(\mathrm{LD}_{50}\right)$ of fipronil and imidacloprid for African-derived Apis mellifera and to assess the motor changes in bees having ingested or contacted a lethal dose $\left(\mathrm{LD}_{50}\right)$ or a sublethal dose $\left(1 / 500^{\text {th }}\right.$ of the $\left.\mathrm{LD}_{50}\right)$ of these insecticides.

\section{MATERIALS AND METHODS}

These experiments were conducted at the Beekeeping Production Area of Lageado Experimental Farm, Faculty of Veterinary Medicine and Animal Science, UNESP, Botucatu, São Paulo, Brazil, 22 $2^{\circ} 0^{\prime} 30.16^{\prime \prime} \mathrm{S} ; 48^{\circ} 25^{\prime} 41.90^{\prime \prime} \mathrm{W}$, with a humid subtropical (Cfa) climate and an average elevation of $623 \mathrm{~m}$.

We utilized foragers of African-derived $A$. mellifera L. (Hymenoptera: Apidae), collected from five colonies free of diseases or parasites, each with a naturally mated queen. These bees initiate foraging when they are approximately 23 days old (Winston 1991). A bee trap was installed in the entrance of the beehive and was closed during the collection of bees; thus, only bees that returned from the field (foragers) were collected. A total of 720 bees was collected between 7:00 a.m. and 8:00 a.m. and anesthetized in a freezer at $-10^{\circ} \mathrm{C}$ for $1-2$ min (Zaluski et al. 2015). Two forms of exposure were used to assess fipronil and imidacloprid toxicity: ingestion of contaminated food and contact with the diluted insecticide.

We utilized the active ingredient (a.i.) fipronil from the commercial formulation used in the field: Regent ${ }^{\circledR} 800 \mathrm{WG}-800 \mathrm{~g}$ a.i. fipronil/kg- $(80 \% \mathrm{~m} / \mathrm{m})$; Inert Ingredients $-200 \mathrm{~g} / \mathrm{kg}(20 \% \mathrm{~m} / \mathrm{m})(\mathrm{BASF}$ Agri-Production SAS) as well as imidacloprid from the commercial formulation Appalus ${ }^{\circledR} 200$ SC-200 g a.i. imidacloprid/L- $(20 \% \mathrm{~m} / \mathrm{v})$; Inert Ingredients- $-892 \mathrm{~g} / \mathrm{L}(89.20 \% \mathrm{~m} / \mathrm{v})$ (Consagro Agroquímica Ltda). Solutions of $1 \mathrm{~g} \mathrm{~L}^{-1}$ Regent $^{\circledR}$ 
800WG and Appalus ${ }^{\circledR} 200$ SC were prepared separately in distilled water and the doses used in all tests were diluted from this solution. For all dilutions used in the present study, we considered only the amount of a.i. fipronil or imidacloprid, not the amount of inert ingredients. No solubility problems were observed. The solutions were stirred vigorously during preparation and prior to use to ensure that they were always at the same concentration.

The oral $\mathrm{LD}_{50}$ was determined according to the methodology described by Miranda et al. (2003) with modifications proposed by Zaluski et al. (2015). Bees were placed in disposable wooden boxes $(25.0 \times 15.0 \times 10.0 \mathrm{~cm})$, with screens on the sides. They remained unfed for $3 \mathrm{~h}$ and then received $1 \mathrm{~mL}$ of food ( $50 \%$ honey syrup) in a plastic tube $(50 \times 10 \times 10 \mathrm{~mm})$. The consumption of $50 \mu \mathrm{L}$, the average uptake by one bee (Crane 1990), was associated with the consumption of 0.00 ; $0.05 ; 0.10 ; 0.20 ; 0.40$, or $0.80 \mu \mathrm{g}$ of fipronil; and $0.000 ; 0.025 ; 0.050 ; 0.100 ; 0.200$, or $0.400 \mu \mathrm{g}$ of imidacloprid. The contaminated food was provided for $3 \mathrm{~h}$ and was then replaced with uncontaminated sugar syrup. The amount of uneaten contaminated food was recorded to check the approximate dose ingested by bees in each box.

To determine the amount of contact constituting the $\mathrm{LD}_{50}$ dose, adult bees were collected, anesthetized, and transferred to a cage (a disposable PET plastic tray, $25 \times 15 \times 10 \mathrm{~cm}$ ). They received $2 \mu \mathrm{L}$ of solution containing different amounts of fipronil $(0.000 ; 0.002 ; 0.004 ; 0.008$; 0.016 , or $0.032 \mu \mathrm{g})$; or imidacloprid $(0.000 ; 0.005$; $0.010 ; 0.020 ; 0.040$, or $0.080 \mu \mathrm{g}$ ) on the thorax, applied with an automatic micropipette (Mettler Toledo Company). Bees received sugar syrup ad libitum during all contact tests (Zaluski et al. 2015).

The doses used to calculate the $\mathrm{LD}_{50}$ were based on preliminary tests. We tested the responses of 10 bees to each dose to determine the ingestion and contact $\mathrm{LD}_{50}$, and all tests were performed in triplicate. Bees that showed behavioral alterations or lethargy before the tests were rejected and replaced by healthy bees. Bees were kept in the dark after consumption of the contaminated food, at room temperature $\left(25 \pm 1{ }^{\circ} \mathrm{C}\right)$, with humidity between 60 and $65 \%$. The number of dead bees in each treatment was recorded $24 \mathrm{~h}$ after the beginning of the tests, and the results were used to calculate the $\mathrm{LD}_{50}$ (Zaluski et al. 2015). In all tests, the mortality in the control groups was less than $5 \%$.

To study motor function in bees exposed to insecticides, we collected 480 adult bees and exposed them by ingestion and contact to an $\mathrm{LD}_{50}$ or sublethal dose of fipronil or imidacloprid. The sublethal dose supplied to bees corresponded to $1 / 500^{\text {th }}$ of the $\mathrm{LD}_{50}$ of ingestion (assuming that a bee ingested $50 \mu \mathrm{L}$ of syrup); and contact determined in the present study. Fipronil $\mathrm{LD}_{50}$ of ingestion and contact were 0.2316 and 0.0080 $\mu \mathrm{g} / \mathrm{bee}$, respectively; and sublethal doses of ingestion and contact were 0.0004 and 0.000016 $\mu \mathrm{g} /$ bee, respectively. Imidacloprid $\mathrm{LD}_{50}$ doses of ingestion and contact were 0.1079 and 0.0308 $\mu \mathrm{g} / \mathrm{bee}$, respectively; and sublethal doses of ingestion and contact were 0.0002 and 0.00006 $\mu \mathrm{g} / \mathrm{bee}$, respectively. The collection and exposure of bees were performed as described for the $\mathrm{LD}_{50}$ measurements.

The motor activity of bees was assessed at 1 and $4 \mathrm{~h}$ after exposure, according to the methodology described in Zaluski et al. (2015). The tests were performed in the laboratory using a wooden box $(60 \times 35 \times 04 \mathrm{~cm})$ divided into 5 lanes $(50 \times 05 \times$ $04 \mathrm{~cm}$ ), containing a fluorescent lamp in the top and covered with glass through which the bees could be observed. The tests were performed in the dark, with the box tilted at $45^{\circ}$ and the lamp turned on, stimulating locomotion of the bees by positive phototaxis (Lambin et al. 2001). The bees were released into the box, one per lane, and the time that it took each bee to travel $50 \mathrm{~cm}$ was recorded. 
For each tested dose and each time assessed, 10 bees were exposed to fipronil and imidacloprid, and 10 served as controls. All tests were performed in triplicate.

The ingestion and contact $\mathrm{LD}_{50}$ were determined on the basis of mortality of bees per dose, using probit analysis with maximum likelihood. The results of the motor activity analyses were first tested for normality (AndersonDarling test) and homogeneous variance (Levene's test); if significant deviations were detected ( $p<$ $0.05)$, the data were compared by non-parametric Mann-Whitney $U$ test and presented as the median and interquartile intervals (Q1-Q3). A $p$ value of less than 0.05 was considered significant. Data analyses were performed using Minitab statistical software (v. 17, State College, PA).

\section{RESULTS}

The mean ingestion and contact $\operatorname{LD}_{50}(24 \mathrm{~h})$ of fipronil and imidacloprid for African-derived $A$. mellifera are $0.2316 \pm 0.0626$ and $0.0080 \pm 0.0021$ $\mu \mathrm{g} / \mathrm{bee}$; and $0.1079 \pm 0.0375$ and $0.0308 \pm 0.0218$ $\mu \mathrm{g} / \mathrm{bee}$, respectively (Table I). Both insecticides were more toxic when administered by contact than by ingestion.

Bees that received the $\mathrm{LD}_{50}$ of fipronil or imidacloprid by either route took longer to walk through the $50-\mathrm{cm}$ track in motor activity tests than did bees in the control groups at all observation times (Table II). Bees that received the sublethal dose of fipronil by either route took longer to walk through the 50-cm track in motor activity tests than did bees in the control groups at all observation times. No differences were observed after ingestion or contact exposure to the sublethal dose of imidacloprid (Table II).

\section{DISCUSSION}

In this study, we showed that fipronil and imidacloprid insecticides are highly toxic and
TABLE I

Mean ingestion and contact lethal doses $\left(\mathrm{LD}_{50}\right.$ at $\left.24 \mathrm{~h}\right)(\mu \mathrm{g} /$ bee) and slopes in the probit analysis of the insecticides fipronil and imidacloprid for African-derived Apis mellifera.

\begin{tabular}{ccccc}
\hline Insecticide & $\begin{array}{c}\text { Ingestion } \\
\mathbf{L D}_{\mathbf{5 0}}\end{array}$ & Slope & $\begin{array}{c}\text { Contact } \\
\text { LD }_{\mathbf{5 0}}\end{array}$ & Slope \\
\hline Fipronil & $0.2316 \pm$ & 1.93 & $0.0080 \pm$ & 1.87 \\
& 0.0626 & & 0.0021 & \\
Imidacloprid & $0.1079 \pm$ & 1.39 & $0.0308 \pm$ & 1.27 \\
& 0.0375 & & 0.0218 & \\
\hline
\end{tabular}

Data are presented as the mean and standard deviations.

TABLE II

Time (seconds) spent by African-derived Apis mellifera walking along a 50-cm track after exposure to the lethal dose $\left(L D_{50}\right)$ or sublethal dose $\left(1 / 500^{\text {th }}\right.$ of the $\left.L D_{50}\right)$ of fipronil or imidacloprid, by ingestion or contact, at 1 and $4 \mathrm{~h}$ after exposure.

\begin{tabular}{ccccc}
\hline & \multicolumn{2}{c}{ Lethal Dose $\left.\mathbf{( L D}_{50}\right)$} & \multicolumn{2}{c}{ Sublethal Dose } \\
\hline Treatment & $1 \mathrm{~h}$ & $4 \mathrm{~h}$ & $1 \mathrm{~h}$ & $4 \mathrm{~h}$ \\
Control & 10 & $8(4-12)$ & $4(4-5)$ & $7(5-7)$ \\
& $(5-12)$ & & & \\
Ingestion & 20 & 13 & 8 & 12 \\
fipronil & $(14-26)^{*}$ & $(10-17)^{*}$ & $(7-10)^{*}$ & $(8-14)^{*}$ \\
Control & $7(5-15)$ & $7(5-15)$ & $5(4-6)$ & $6(5-7)$ \\
$\begin{array}{c}\text { Contact } \\
\text { fipronil }\end{array}$ & 22 & 21 & 12 & 9 \\
& $(15-38)^{*}$ & $(10-39)^{*}$ & $(9-13)^{*}$ & $(8-12)^{*}$ \\
Control & $4(4-5)$ & $7(5-7)$ & $8(6-11)$ & 15 \\
& & & & $(6-21)$ \\
$\begin{array}{c}\text { Ingestion } \\
\text { imidacloprid }\end{array}$ & $(14-21)^{*}$ & $(9-12)^{*}$ & $(7-20)$ & $(12-27)$ \\
Control & $5(4-6)$ & $6(5-7)$ & 11 & 10 \\
Contact & 8 & 10 & 11 & 11 \\
imidacloprid & $(7-10)^{*}$ & $(9-13)^{*}$ & $(7-14)$ & $(7-15)$ \\
\hline
\end{tabular}

Data are presented as the median and interquartile intervals (Q1-Q3). * $p<0.01$ compared to control group by MannWhitney $U$ test, within a single time bracket $(n=30)$.

induce motor activity changes in African-derived $A$. mellifera. Insecticides are considered toxic to bees when the $\mathrm{LD}_{50}$ is less than $2 \mu \mathrm{g}$ per bee (Johansen and Mayer 1990). The values of ingested and contacted fipronil $\mathrm{LD}_{50}$ presented in this study are within the ranges reported by Carrillo et al. (2013) and Zaluski et al. (2015). Toxicity data from Agence Nationale de Sécurité Sanitaire de l'Alimentation (France) reported $\mathrm{LD}_{50}$ doses of ingestion and 
through contact of 0.00417 and $0.00593 \mu \mathrm{g}$ fipronil/ bee, respectively (AgriTox Database, 2015). The ingested $\mathrm{LD}_{50}$ values for imidacloprid are similar to those reported by Carrillo et al. (2013), and the contact tests are within the ranges reported by Cresswell (2011). Suchail et al. (2000) reported ingested $\mathrm{LD}_{50}$ values of imidacloprid about 0.005 $\mu \mathrm{g} / \mathrm{bee}$; and after contact application, the $\mathrm{LD}_{50}$ values were approximately $0.024 \mu \mathrm{g} / \mathrm{bee}$ for $A$. $m$. mellifera and $0.014 \mu \mathrm{g} /$ bee for $A$. m. caucasica.

The oral $\mathrm{LD}_{50}$ of fipronil and imidacloprid were higher when determined by contact exposure; this may be attributed to the action of detoxification enzymes that act when bees are exposed to pesticides orally. These detoxification enzymes are present in the digestive system, liver, or Malpighian tubules of honey bees (Miranda et al. 2003). However, regardless of the route of exposure, both pesticides presented high toxicity to adult bees and this fact emphasizes the importance of regulating the application of these insecticides during the flowering periods of crops attractive to bees.

Fipronil has an antagonistic action on gamma amino butyric acid (GABA) neurotransmitters and glutamate-activated chloride channels (Glu Cls) (Narahashi et al. 2010), and this insecticide can cause behavioral changes in bees that include agitation, spasms, tremors, and paralysis (Zaluski et al. 2015). Unlike fipronil, imidacloprid acts as an agonist to nicotinic acetylcholine receptors (nAChRs) present in high density in insect nervous tissue (Brown et al. 2006). Suchail et al. (2000) describe neurotoxic symptoms such as movement coordination problems, trembling, and tumbling in bees exposed to imidacloprid. The high toxicity and the behavioral changes that can occur in honey bees foraging in contaminated fields can reduce the performance and maintenance of whole colonies.

Phenylpyrazole and neonicotinoid insecticides differ from classic insecticides in that they become systemic in the plant, and can be detected in pollen and nectar throughout the blooming period (Ellis 2010). This study demonstrates that bees exposed to $\mathrm{LD}_{50}$ of fipronil and imidacloprid experience motor changes. Evaluating motor changes in bees exposed to $\mathrm{LD}_{50}$ of fipronil and imidacloprid in the lab simulates acute toxicity of bees exposed to these pesticides in natural or agricultural ecosystems immediately after sprayed.

In sublethal doses, bees exposed to fipronil by ingestion and contact showed impaired motor activity; this did not occur with imidacloprid. Some pesticides can be metabolized to different compounds in insects (Singh 2012), and depending on the route of exposure and the dose, they can have reduced toxicity due to the action of detoxification enzymes (Miranda et al. 2003). Thus, the low amount of imidacloprid in the sublethal dose may be insufficient to cause motor changes by itself; however, the active substance or metabolites formed in the sublethal dose of fipronil may not be inactivated by detoxification enzymes, impairing motor function in honey bees. This study suggests that fipronil is more toxic that imidacloprid in sublethal doses, impairing the motor activity of bees. It is important to recognize that in this study, honey bees were exposed only once to the doses of fipronil and imidacloprid, and that in fields where these pesticides are sprayed, bees can suffer a repetitive exposure that can cause major damage.

Exposure to fipronil and imidacloprid while bees are collecting nectar, pollen, water, and resin, as well as the presence of these pesticides or metabolites in stored products in colonies of $A$. mellifera (Chauzat et al. 2006, Pareja et al. 2011) represent a risk for these pollinators, which may result in behavioral changes (Zaluski et al. 2015, Suchail et al. 2000) and impaired motor activity. Proper motor activity is essential to forager bees collecting resources for a colony; bees also communicate to unemployed nestmate foragers the location of food using a dance language (Von Frisch 1967). The exposure of bees to fipronil 
and imidacloprid can lower the global fitness of the colonies and harm their maintenance. Studies conducted by Zaluski et al. (2015) demonstrate dramatic negative effects of a sublethal dose of fipronil to colonies and show colony maintenance completely hindered.

Further studies are necessary to evaluate the safety of the use of fipronil and imidacloprid in areas in which bees collect resources, including the duration that residual systemic pesticides may be present in the environment and contaminating plants that are attractive to bees. Determining the realistic field exposure of insect pollinators to fipronil and imidacloprid is essential, because, as this study demonstrates, even in sublethal doses, fipronil can cause impairment of motor functions in bees and hinder their performance. The use of these insecticides should be restricted in crops that could present a contamination risk to bees, and measures should be undertaken to replace fipronil, imidacloprid and associated insecticides with products that have lower toxicity to pollinators.

\section{ACKNOWLEDGMENTS}

To the Conselho Nacional de Desenvolvimento Científico e Tecnológico (CNPq) for the scholarship granted to the first author.

\section{REFERENCES}

AGRITOX DATABASE. 2015. Base de données sur les substances actives phytopharmaceutiques: Fipronil. [Cited 2015 November 06]. Available from: <http://www.agritox. anses.fr/php/sa.php?sa=1134>.

BONCRISTIANI H, UNDERWOOD R, SCHWARZ R, EVANS JD, PETTIS J AND VAN ENGELSDORP D. 2012. Direct effect of acaricides on pathogen loads and gene expression levels in honey bees Apis mellifera. J Insect Physiol 58: 613-620.

BROWN LA, IHARA M, BUCKINGHAM SD, MATSUDA K AND SATTELLE DB. 2006. Neonicotinoid insecticides display partial and super agonist actions on native insect nicotinic acetylcholine receptors. J Neurochem 99: 608615.
CARRILLO MP, BOVI TS, NEGRÃO AF AND ORSI RO. 2013. Influence of agrochemicals fipronil and imidacloprid on the learning behavior of Apis mellifera L. Acta Sci Anim Sci 35: 431-434.

CHAUZAT MP, FAUCON JP, MARTEL AC, LACHAIZE J, COUGOULE N AND AUBERT M. 2006. A survey of pesticide residues in pollen loads collected by honey bees in France. J Econ Entomol 99: 253-262.

CIARLO TJ, MULLIN CA, FRAZIER JL AND SCHMEHL DR. 2012. Learning impairment in honey bees caused by agricultural spray adjuvants. PLoS ONE 7: e40848.

CRANE E. 1990. Bees and beekeeping: science practice and world resources, $1^{\text {st }}$ ed., Oxford: Heinemann Newnes, 640 p.

CRESSWELL J. 2011. A meta-analysis of experiments testing the effects of a neonicotinoid insecticide (imidacloprid) on honey bees. Ecotoxicology 20: 149-157.

ELLIS M. 2010. Pesticides applied to crops and honey bee toxicity. University of Nebraska, Lincoln. [Cited 2015 February 20]. Available from: <http://www.beeccdcap. uga.edu/documents/CAPArticle7.html $>$.

ENVIRONMENTAL PROTECTION AGENCY. 2015. Colony collapse disorder: European bans on neonicotinoid pesticides. [Cited 2015 February 20]. Available from: $<$ http://www.epa.gov/pesticides/about/intheworks/ccdeuropean-ban.html>.

GHISI NC, RAMSDORF WA, FERRARO MV, ALMEIDA MI, RIBEIRO CA AND CESTARI MM. 2011. Evaluation of genotoxicity in Rhamdia quelen (Pisces, Siluriformes) after sub-chronic contamination with fipronil. Environ Monit Assess 180: 589-599.

HENRY M, BÉGUIN M, REQUIER F, ROLLIN O, ODOUX JF, AUPINEL P, APTEL J, TCHAMITCHIAN S AND DECOURTYE A. 2012. A common pesticide decreases foraging success and survival in honey bees. Science 336 : 348-350.

JOHANSEN CA AND MAYER DF. 1990. Pollinator protection: a bee $\&$ pesticide handbook, $1^{\text {st }}$ ed., Cheshire (Conn.): Wicwas Press, $212 \mathrm{p}$.

KLEIN AM, VAISSIÈRE BE, CANE JH, STEFFANDEWENTER I, CUNNINGHAM SA, KREMEN C AND TSCHARNTKE T. 2007. Importance of pollinators in changing landscapes for world crops. Proc Biol Sci 274: 303-313.

LAMBIN M, ARMENGAUD C, RAYMOND S AND GAUTHIER M. 2001. Imidacloprid-induced facilitation of the proboscis extension reflex habituation in the honeybee. Arch Insect Biochem Physiol 48: 129-134.

LEBUHN G ET AL. 2013. Detecting insect pollinator declines on regional and global scales. Conserv Biol 27: 113-120.

MIRANDA JE, NAVICKIENE HMD, NOGUEIRA-COUTO RH, DE BORTOLI SA, KATO MJ, BOLZANI VS AND FURLAN M. 2003. Susceptibility of Apis mellifera 
(Hymenoptera: Apidae) to pellitorine, an amide isolated from Piper tuberculatum (Piperaceae). Apidologie 34: 409-415.

NARAHASHI T, ZHAO X, IKEDA T, SALGADO VL AND YEH JZ. 2010. Glutamate-activated chloride channels: unique fipronil targets present in insects but not in mammals. Pestic Biochem Physiol 97: 149-152.

NICODEMO D, MAIOLI MA, MEDEIROS HCD, GUELFI M, BALIEIRA KVB, DE JONG D AND MINGATTO FE. 2014. Fipronil and imidacloprid reduce honeybee mitochondrial activity. Environ Toxicol Chem 33(9): 2070-2075.

OLDROYD PB. 2007. What's killing American honey bees? PLoS Biol 5(6): e168.

PAREJA L, COLAZZO M, PÉREZ-PARADA A, NIELL S, CARRASCO-LETELIER L, BESIL N, CESIO MV AND HEINZEN H. 2011. Detection of pesticides in active and depopulated beehives in Uruguay. Int J Environ Res Public Health 8: 3844-3858.

SCHNEIDER CW, TAUTZ J, GRÜNEWALD B AND FUCHS S. 2012. RFID tracking of sublethal effects of two neonicotinoid insecticides on the foraging behavior of Apis mellifera. PLoS ONE 7: e30023.

SILVA CRUZ A, SILVA-ZACARIN EC, BUENO OC AND MALASPINA O. 2010. Morphological alterations induced by boric acid and fipronil in the midgut of worker honeybee (Apis mellifera L.) larvae. Cell Biol Toxicol 26: 165-176.

SINGH DK. 2012. Toxicology: agriculture and environment: pesticide chemistry and toxicology, $1^{\text {st }}$ ed., Bentham Science Publishers, 213 p.

STOKSTAD E. 2007. The case of the empty hives. Science 316: 970-972.
SUCHAIL S, GUEZ D AND BELZUNCES LP. 2000. Characteristics of imidacloprid toxicity in two Apis mellifera subspecies. Environ Toxicol Chem 19: 19011905.

VAN ENGELSDORP D ET AL. 2009. Colony collapse disorder: a descriptive study. PLoS ONE 4: e6481.

VAN ENGELSDORP D AND MEIXNER MD. 2010. A historical review of managed honey bee populations in Europe and the United States and the factors that may affect them. J Invertebr Pathol 103: S80-S95.

VON FRISCH K. 1967. The dance language and orientation of bees. Cambridge: Harvard University Press, 592 p.

WHITEHORN PR, O'CONNOR S, WACKERS FL AND GOULSON D. 2012. Neonicotinoid pesticide reduces bumble bee colony growth and queen production. Science 336: 351-352.

WILLIAMS GR, TARPY DR, VAN ENGELSDORP D, CHAUZAT MP, COX-FOSTER DL, DELAPLANE KS, NEUMANN P, PETTIS JS, ROGERS REL AND SHUTLER D. 2010. Colony collapse disorder in context. Bioessays 32: 845-846.

WINSTON ML. 1991. The biology of the honey bee. Cambridge: Harvard University Press, 281 p.

ZALUSKI R, KADRI SM, ALONSO DP, RIBOLLA PEM AND ORSI RO. 2015. Fipronil promotes motor and behavioral changes in honey bees (Apis mellifera) and affects the development of colonies exposed to sublethal doses. Environ Toxicol Chem 34: 1062-1069. 